\title{
Other Headings
}

\section{Birgit Kaiser \& Kathrin Thiele}

To cite this article: Birgit Kaiser \& Kathrin Thiele (2016) Other Headings, Interventions, 18:2, 270-285, DOI: 10.1080/1369801X.2015.1106965

To link to this article: http://dx.doi.org/10.1080/1369801X.2015.1106965

曲 Published online: 03 Nov 2015.

13 Submit your article to this journal 저

LII Article views: 215

Q View related articles $\sqsubset$

View Crossmark data 


\title{
OTHER HEADINGS
}

Ben Jelloun, Derrida, Sansal and the Critique of Europe

\section{Birgit Kaiser and Kathrin Thiele}

\author{
Utrecht University, Netherlands
}

\begin{abstract}
............... This essay diffracts the question of the heading of Europe that Derrida asked

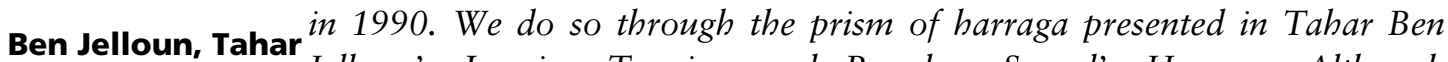
Jelloun's Leaving Tangiers and Boualem Sansal's Harraga. Although critique Europe as the capital has been 'de-identified' (Derrida 1992, 75) in the Derrida, Jacques wake of decolonization and postcolonial critique, it still has to be deidentified always anew. Something has been promised in its name and is, European borders we suggest, currently most forcefully reclaimed by people who 'burn up the harraga road'. Listening to these claims is vital for any future 'Europe' because the responses currently presented by 'Europe' are still either self-identification Sansal, Boualem and closure or aversion from Europe altogether. With reference to Derrida, this essay insists on the necessity to take note of and affirm that Europe ............... must 'open itself onto the other shore of another heading'. Derrida was hopeful ('that is already at work anyway'), underneath and alongside the closure of borders since the early 1990s and the increase in clandestine migration. Although we see mainly symptoms of radical closure, with Derrida and the harragas this essay asserts it can be otherwise - that it is Europe's brutal failure to ignore this call of the heading of the others, forestalling any chance for an 'other of the heading'. It is thus 'Europe's' duty to listen to the (re)call of these others.
\end{abstract}


1 All translations of Sansal are our own. An English translation is available with Bloomsbury 2015.

2 As Derrida (1992, 35) stresses, the point of Europe has much to do with how it conceives of its heading, a semantic doubling inherent in the French as le point (a place, position, mark) and la pointe (a head, end, headland).
Leaving the country. It was an obsession, a kind of madness that ate at him day and night: how could he get out, how could he escape this humiliation? Leaving, abandoning this land that wants nothing more to do with its children, turning your back on such a beautiful country to return one day, proudly, perhaps as a rich man: leaving to save your life, even as you risk losing it... He thought it all over and couldn't understand how he'd reached such a point. The obsession quickly became a curse ... (Ben Jelloun 2009, 10)

What is it 'to respond'? To respond to? To be responsible for? To respond for? To respond, be responsible, before? (Derrida 1992, 53)

There are walls caving in, calamities to which the government has abandoned us, and all the fears, the terrible fears, of a life on hold.

What to do when all routes are blocked?

Let's burn up the road

The promised Land is somewhere in the world.

(Sansal 2005, 239-240) ${ }^{1}$

Three voices of-on-from-for-toward 'Europe' - Tahar Ben Jelloun, Jacques Derrida, Boualem Sansal. Three texts, treating the (self-)images and imaginaries of Europe, are interlaced here to respond to the invitation of this special issue: to reflect on the point of Europe in view of the postcolonial, globalizing and digitalized world of the early twenty-first century. The point or heading ${ }^{2}$ of Europe at (and for) this historical juncture is a pressing matter: not only in view of Europe's colonial legacies that continue to have effects today, but also in view of the recent revivals of East-West divisions that, post-1989, were already thought to be 'of the past'; in view of the many people from African and Middle-Eastern countries seeking refuge in Europe; in view of a growing weariness of Europe, manifested in increasing support across Europe for right-wing parties and their nationalist populism and xenophobic exclusionary rhetoric. It is not only a pressing matter, but also a matter pressed upon us from inside and outside Europe (and asking after the point of Europe might have to include questioning what it means to assume an inside and an outside).

Our concern for the point of Europe here stems not from a renewed desire for European grandeur, a postcolonial melancholia (Gilroy 2005), or a desire to revive modes of self-identification that are imagined as pure, authentic and monolingual. To the contrary, it is a critique of European headings today, and an affirmation of a 'postmonolingual' Europe (Yildiz 2012) that is quite fluid across 'internal' borders, while closing and fortifying its 'external' ones, that concerns us here. Building on Derrida, who responded to the question of the heading of Europe in 1990, we see such a critique as a practice that takes 
responsibility for the heritage of Eurocentrism and (neo)colonialism and with that baggage - negotiates and envisions possible other headings; perhaps not contingently precisely twenty-five years after the declared end of the 'bipolar world' and the 'reunification' of Europe. We want to recall Derrida's critique of Europe and transpose it onto the contemporary European (that is, European-cum-others) scene, for our Europe today. For that purpose we will diffract ${ }^{3}$ Derrida's reflections with critiques of Europe performed in two contemporary novels: Tahar Ben Jelloun's Leaving Tangier (2009) and Boualem Sansal's Harraga (2005).

\section{The Other Heading}

3 We build here on Haraway's (classical physics) and especially Barad's (quantum physics) use of the term diffraction. Diffraction describes, on the one hand, the formation of patterns of difference, stressing the 'relational nature of difference' (Barad 2007,72 ), and on the other hand, the critical reading method that juxtaposes texts in order to draw out significant patterns of meaning-mattering. For the implications of the term, see Barad (2007); for its uses in the humanities, see also Kaiser and Thiele (2014).
In The Other Heading (1992), Derrida asks after the direction Europe takes or might take at the 'today' of 1990, a historical juncture when European power constellations and imaginaries seemed to be redrawn after the Eastern European revolutions, perestroika and the fall of the Berlin Wall. He engages with a reorientation of Europe, taking into account the past centuries in which a Eurocentric and colonialist Europe took itself to be 'la capital' (56), the metropole and head of the world, which Derrida also ties to 'le capital, to the question of what links capital to the theme of European identity' (56). In this tradition, Derrida reminds us:

Europe takes itself to be a promontory, an advance - the avant-garde of geography and history. It ... will have never ceased to make advances on the other: to induce, seduce, produce, and conduce, to spread out, to cultivate, to love or to violate, to love to violate, to colonize, and to colonize itself. (Derrida 1992, 49)

Given this heritage and Europe's reconfiguration after 1989, Derrida considers the direction Europe takes or could take at that juncture. He begins by noting that when he thought about a title for his talk, 'the language of the air or sea navigation' came to mind - since 'on the sea or in the air, a vessel has a "heading": it "heads off", toward another continent, toward a destination that is its own but that it can also change' (13). Drawing on metaphors of navigation, he reflects on what it might imply to 'think today ... for a Europe torn away from self-identification as repetition of itself ... a singular advent of Europe, here and now' (12) beyond the exhausted programmes of Eurocentrism, Cold War politics and (neo)colonial aspirations. 'How does one respond?' (29), Derrida asks; that is, how does one navigate the historical juncture in which constellations of power seem to be rearranged? How can one assume responsibility for a heritage (a Eurocentric modern tradition, Enlightenment, democracy and colonialism) whose denial would be 
4 Derrida's emphasis on the 'today' and his striving to think of 'other headings' - a different Europe - or even of 'the other of the heading' as a different logic to relate to the other, brings to mind two famous public interventions on the issues at stake, which Derrida implicitly draws on: Kant's (1784) and Foucault's (1984) responses to the question 'What is Enlightenment?' It is this specific (European) heritage of critique as public intervention developed by Kant, reworked by Foucault, revisited by Derrida - that we wish to continue in our engagement in this essay.

5 Speaking of a concern or care for Europe in this context makes implicit reference to the reformulations of critique suggested by Haraway (1997), Latour (2004) and Puig de la Bellacasa (2011).

6 The Other Heading engages closely with Valéry's reflections on the

Mediterranean, but irresponsible, yet whose repetition as the same would be equally so? In 1990, for his specific historical moment, Derrida stresses the necessity 'to make ourselves the guardians of an idea of Europe ..., but of a Europe that consists precisely in not closing itself off in its own identity' (29). In order fully to affirm Europe's responsibility for its colonialist heritage and its promise of democracy, the metaphor of the heading is fruitful because it also harbours the possibility of changing direction. Unravelling the title, Derrida writes:

But beyond our heading, it is necessary to recall ourselves not only to the other heading, and especially to the heading of the other, but also perhaps to the other of the heading, that is to say, to a relation of identity with the other that no longer obeys the form, the sign, or the logic of the heading, not even of the antiheading - of beheading, of decapitation. (Derrida 1992, 15)

It is this triangular interplay of vectors and perspectives that we would like to engage with in this essay: the other heading (of Europe), the heading of the other, and the possible horizon of an other of the heading; that is, another 'logic', if you will, that departs from (this or that) direction, without falling for yet (merely) another heading. ${ }^{4}$ An exploration of the point of Europe today needs to take these three vectors into account, precisely in order to avoid 'self-identification as repetition of itself'. A concern for Europe, a care for a shift in direction - away from discourses of security and 'external' border-control or the reviving nationalisms of a populist, traditionalist, (proto-)fascist or homonationalist (Puar 2007) nature, and towards an open, hospitable terrain - cannot, Derrida notes already for 1990, merely be self-referential, and in times of globalization and increased migration flows perhaps even less so than a few decades earlier. ${ }^{5}$ If Europe is to take another direction today, it has to account for and respond to the headings of the other(s) - to perhaps then even reopen the horizon for modes of cohabitation that do not validate themselves by narratives of direction, progress, telos, heading, or the repetitive loops of inclusion/exclusion.

We also have to note that the registers of navigation in sea and air travel that Derrida refers to when commenting on the title of his talk not only serve as suitable metaphors. In addition, literal travel between two (or more) shores is central to Derrida's argument as it is to this essay: an understanding of culture and cultural identification as never self-identical and as involving many literal, physical crossings of borders and oceans. Specifically, the crossings of the Mediterranean are significant to us here - not only as crossing the marine space that connects Europe to other shores, but also as the focal point of Derrida's engagement with the question ${ }^{6}$ and this essay's reflection on the contemporary headings of Europe. It is thus the Mediterranean crossings of migrants and refugees to Europe that are our anchor point here. We wish to revisit a critique of Europe - to venture 'a new critique of the new effects of 
the Mediterranean is also integral to Derrida's own biography. Since the publication of The Other Heading, the 'marrano' dimensions of Derrida's thought, his reflections on his own Mediterranean heritage and JewishAlgerian childhood have increasingly been topics in his own work (Derrida 1991, 1996, 2002; Chérif 2008b) and in scholarship alike. Perhaps one of the first to mention the relation of Derrida's philosophy to his experiences on Europe's other shores was Young (1990); see also Chérif (2008a), Ahluwalia (2010) and Hiddleston (2010). 7 Naas notes in his introduction to The Other Heading that 'navigation could never be a mere metaphor' (xliv). Yet a Eurocentric, (neo) colonial Europe, thinking of itself as the capital of culture, tends to present it 'always ... as a mere metaphor' (xlv), eclipsing the literal level of "explorations of other lands, other peoples, and other ways of thinking' (xlv). 8 Since the 1990s, harraga - from the Arabic root 'ha-raqaf' meaning 'to burn' - has become a term used especially in the French media capital' (Derrida 1992, 57) - by considering these headings of the others who risk their lives to come to Europe. In view of this, the metaphors of navigation have surely lost the innocence or metaphoricity we may have felt it legitimate to attribute to them in $1990 .^{7}$ Today, they drive home the question of European headings with particular force: who can head where, within or into Europe; how and at the expense of what; and where is 'Europe' heading with/in all of this, clearly no longer as the head or captain of universal history, but a provincialized Europe (Chakrabarty 2000), yet one that practices again unprecedented self-enclosure and expulsion (Sassen 2014).

The realities to which Derrida responded in 1990 are different from the realities of the early twenty-first century. Thus, additionally, before we begin, we want to stress that the aim of our essay is neither to 'apply' Derrida's thoughts to a different, that is contemporary, situation, nor is it to 'apply' a philosophical reflection to literary texts. Rather, what we aim at is an interlacing of three voices on the challenges of Europe - one 'philosophical' and two 'literary' expositions of the actual and possible headings of the configuration called Europe. Taking up Derrida's threefold use of the heading - a critique of Europe's heading, a consideration of the heading of the other, and a gesture towards 'the other of the heading' - and reading it in light of the current streams of migration, a reading in turn aided by two exemplary novels by Ben Jelloun and Sansal, which we regard as (affirmative) critiques of Europe, is our way here to a/effectively ask the question of the point of Europe today. It is not a new question, but one that needs to be asked again and always anew for each 'today'. And it is a question that - for us - forcefully crystallizes, at this juncture, in relation to the phenomenon of harraga, (no longer so clandestine) migration across the Mediterranean. ${ }^{8}$

In Ben Jelloun's novel Leaving Tangier, to which we will return in detail in a moment, Azel - one of the protagonists who wants to leave Morocco for Spain in search of a better life - is very aware of the fortified borders of Europe at the turn of the twenty-first century:

Now the Moroccans would just have to behave themselves! No more dreaming about Spain, thanks to a new law and all those technical innovations. At the slightest suspicion, the lights of the Guardia Civil pop on and the electronic gear detects the would-be emigrant, who will be turned back before he even leaves his house. (Ben Jelloun 2009, 27)

Azel refers here to the implementation of increased surveillance along the Spanish coast, preceded by Spain's introduction of a visa requirement for Moroccans in 1991 and followed by the increased 'fortification' of the Mediterranean coast as a whole, resulting from the Schengen integration of the European Union. It is, as Abderrezak notes, this “"militarization” ... of the 
for migrants who emigrate

clandestinely to

Europe across the

Mediterranean. 'To

burn' refers here both

to the burning of

identification papers

to avoid repatriation

and to 'burn the road'

('brûler la route'). We

use the transcription

harraga (see

Abderrezak 2009,

469), and according

to common usage

employ harraga when

referring to

clandestine

migration, and

harragas when

referring to the ones

migrating.

9 As Barad reminds us, every today is 'an iterative (re)

configuring of

patterns of

differentiating-

entangling. As such,

there is no moving

beyond, no leaving

the "old" behind.

There is no absolute

boundary between

here-now and there-

then. There is nothing

that is new; there is

nothing that is not

new' $(2014,168)$.
Mediterranean [that] has forced migrants to travel along clandestine routes' (2009, 461). In line with Abderrezak's observation, we argue that any heading of Europe today is specifically entangled and concerned with these harragas, the clandestine migrants who set out for Europe across the Mediterranean. Any route that 'Europe' might take, or does take, is in relation to these others - whether or not this is acknowledged discursively and practically. In recent years specific European responses have taken mainly two directions (both of which make necessary the call for a different heading): along the borders, the response has been increased patrols, detention camps and deportation (Carr 2012); within borders, as El-Tayeb forcefully argues, it has been a reaffirmed image of Europe as raceless; that is, homogeneously white, discursively largely precluding internal racial (and religious) difference(s). As one example, El-Tayeb points to the 2008 inaugural exhibition of the Brussels Museum of Europe, 'It's Your History', showcasing Europe as racially homogeneous (2011, 163-167), a selfimagination that is coupled with the idea that decolonization inaugurated an era in which former European colonial powers 'can concentrate on Europe' and no longer have to 'involve themselves with problems outside of Europe' (as quoted in El-Tayeb 2011, 165).

If we desire different headings for Europe - perhaps even a different Europe - revisiting Derrida's critical reflections on Europe in light of the contemporary phenomenon of harraga might sketch routes along which to reopen our 'today': permitting a re-turn (to) Europe - as 'the duty to respond to the call of European memory, to recall what has been promised under the name of Europe' (Derrida 1992, 76) - and affirming that it is not a question of leaving Europe behind because of its problematic histories, but of re-turning (to) it in such ways that we can imagine it otherwise than a narrative of closure and sameness. ${ }^{9}$

\section{Harraga - The Headings of Others}

Europe today has to be understood as entangled with and responding to the complex phenomenon of harraga. These movements of migration have to be taken into account in any question about Europe's heading - certainly alongside other migratory movements, social tensions and injustices, yet harraga currently seems to put Europe to a specific test. Harraga is not a 'problem outside of Europe' as the rhetoric of the Museum of Europe 'might have wished to suggest'. It is rather a situation that is part and parcel of Europe, shaped by and shaping 'Europe' and 'Africa' simultaneously. It is not coming from the 'outside', so that a presupposed 'inside' of Europe needs to 
10 Entanglement is understood not as the interlinking of two independent entities, but as antra-action (Barad 2007). Entities such as 'Europe' or 'Africa' emerge through intra-active relationality, which undercuts traditional ideas of 'inside' and 'outside'. See also Kirby (2011).
11 The numbers and dates in this paragraph relate to the moment of writing in June 2014. Since then, so much has happened and the migration - both by sea and by land - has increased immensely, both in number of people and in media and public attention. In relation to the question of migration, it seems right at this moment impossible to be 'in time'. find a solution for it; instead, we claim it is a phenomenon intimately entangled with Europe, ${ }^{10}$ to which Europe has always already responded, even if currently in destructive ways. The task, therefore, is to come to an understanding of the effects and complex factors of the co-constitution of Europe within a force-field of past, present and future migrations. A fullyfledged response to this entangled constellation would of course require a much greater study than this essay can provide, and we can only draw attention to the question and insist on harraga as a symptom (a kind of diffraction apparatus) that demands: that 'we' reexamine the directions Europe is taking and how these are/will be/will have been entangled with the headings of others.

In an interview with Hakim Abderrezak, Boualem Sansal notes:

The haraga is no longer an individual and marginal phenomenon which threw a few young unemployed onto the routes of clandestine emigration in order to reach Europe ... it has become a complex and polymorphic mass phenomenon which touches all countries that were colonized for a long time and that have not succeeded in their passage to independence and democracy ... It is the tragic history of entire nations that search for a destiny which matches their dreams and their struggles. (Abderrezak 2010, 341)

To get a sense of the magnitude and diversity of those who head for Europe, we only need to recall recent mediatized incidents in which boats of migrants capsized or were found in distress on the Mediterranean; incidents which also reveal the great danger of these crossings, as well as the 'mere' policy measures taken in response to them. On two consecutive days in early January $2014,{ }^{11}$ more than a thousand people - primarily from Egypt, Eritrea, Iraq, Mali, Nigeria, Pakistan, Somalia, Tunisia and Zambia - were found in boats off the coast of the island of Lampedusa by Italian coastguards. They were escorted to Sicily (BBC News, 3 January 2014). On 3 October 2013, a boat heading from Mirata (Libya) to Lampedusa, with approximately five hundred migrants from Ghana, Eritrea and Somalia on board, sank off the island's shores, with three hundred and sixty or more drowned. On 11 October 2013, a boat carrying more than two hundred migrants from Syria and Palestine capsized and sank, killing thirty-four (BBC News, 12 October 2013). According to the UNHCR and Frontex (the EU's external border security agency), the number of migrants who came to Italy by sea in 2013 is estimated at 30,100 (Frontex $2013,45)$ - an increase from an estimated 13,200 in 2012, mainly due to the war in Syria (UNHCR 2013). However, as earlier media coverage shows (whose sporadicalness makes us painfully aware of the number of shipwrecks and deaths that go unnoticed by the international press and the coastguards), the phenomenon is not solely recent: on 21 May 2007 a crowded boat was sighted south of Malta before it went missing (BBC News, 25 May 2007); on 
27 March 2009 a boat capsized off the Libyan coast carrying an estimated two hundred and fifty people, of which twenty-one were rescued (BBC News, 31 March 2009); on 6 April 2011 a boat heading from Libya to Italy sank, carrying an estimated two hundred people from Bangladesh, Chad, Ivory Coast, Nigeria, Somalia and Sudan, of whom forty-eight were rescued (Guardian, 6 April 2011). In 2007 the International Centre on Migration Policy Development estimated that at least ten thousand people died in attempts to reach Europe by boat between 1997 and 2007 (BBC News, 9 July 2007), while in October 2013 the UNHCR estimated the death toll since 1988 at 19,142 (BBC News, 12 October 2013). These numbers do not include those who are waiting - often for years in camps outside Melilla or Ceuta (Spanish enclaves at the North African coastline), or those who take other routes to head towards Europe.

Given the diverse countries of origin, harraga cannot be relegated to a current state of emergency caused 'merely' by local crises - although these can force more people to migrate, as the war in Syria does. Nor can it be explained, as Sansal and Ben Jelloun convincingly convey in their accounts, as a merely economic phenomenon, resulting only from material deprivation. Economic factors are often implied as the cause, but they only partly explain harraga. Sansal is not persuaded by the argument that it is mainly for reasons of 'poverty, unemployment, the violence of political power, the attraction of the West' that people migrate (Abderrezak 2010, 341). 'These are important, yet not determining factors'; he sees as an underlying, deeper cause a sense of deprivation of country (space) and future (time) - 'they have made harragas of us, that is to say people without country and without future' (341), a spatiotemporal disappointment related to the fact that 'the passage to independence ... has been experienced as a failed rite of passage, that did not succeed to open the doors to the future, to fortune, to deliverance' (341). And it not only affects those who decide to migrate. In Sansal's novel Harraga, the protagonist Lamia, who stays in Algeria and does not consider 'burning up the road', calls herself a harraga. After watching a televised documentary on harragas from Niger and Chad, for example, she thinks: 'I now feel harraga at heart' (Sansal 2005, 240). And at the end of the novel - after she has taken in the new-born baby of Chérifa, a young woman who did wish to migrate, and who died on the way while giving birth - she sings to the child: 'My child / My love / My heart, my life / like your mother, my sister, we will be harragas' (317). It is less material deprivation, and more deprivation of a future that both Leaving Tangier and Harraga foreground - feelings of suffocation and lack of prospects are important factors in their (fictive) accounts of

12 A new literary genre has begun to form around harraga (see Poel 2011). From among numerous novels such as clandestine migration to Europe. ${ }^{12}$

This sense of suffocation is a central motif in Sansal's Harraga (2005). The novel narrates the story of Lamia, a middle-aged nurse, living a withdrawn life in Algiers since the disappearance of her brother Sofiane, who 'had taken the route of the harragas, the burners of the road' (53). Told from her perspective, 
Cannibales (1999) by Mahi Binebine, Les Clandestins (2000) by Youssouf Amine Elalamy, and Harraga (2002) by Antonio Lozano (for more titles, see Redouane 2008), and films such as Harragas (2009) by Merzak Allouache and Terraferma (2011) by Emanuele Crialese, we have selected Ben Jelloun's Leaving Tangier and Sansal's Harraga because they examine in exemplary fashion the diverse reasons to leave, rather than pursue tragedies of shipwreck (as in Elalamy), existence sans papiers, or violence and desperation at sea (as in Allouache).

13 Chérifa had intended to 'leave for Morocco, for Spain' (Sansal 2005, 113) but crossed paths with Sofiane on his way to Morocco, who told her it was too dangerous 'to burn up the road in my condition' (113) and that she should rather head for Algiers to stay with Lamia for the birth. Chérifa is a breath of fresh air in Lamia's solitary and dejected life, mourning Sofiane's disappearance. Eventually, Chérifa leaves again for unspecified reasons, and Lamia only learns as the one who stays behind, the novel begins when 16-year-old and pregnant Chérifa knocks on Lamia's door, asking if she can stay in her house for a while. Growing increasingly fond of the young woman, who, like Lamia's brother, is determined to leave the country, Lamia reflects throughout the novel on the phenomenon of harraga - a word that is 'the best known in the country' (53). When she recalls her brother's disappearance, she says this about those 'who burn':

One morning, at day-break, he left. By the Western route, the most dangerous one, Oran, the border, Morocco, Spain, from there onwards, France, England, elsewhere, that is the drill. I heard it late that evening from one of his comrades ... They were many, an entire continent, already drunken with lamentations, dreaming out loud, convincing each other that the world was waiting for them with flowers and that their exodus would deal the fatal blow to the despot's career. In short, they had the fever. (Sansal 2005, 52)

Sansal describes here the wish to leave as a collective fever, 'a mass exodus ... collective suicide' (132); in Ben Jelloun's Leaving Tangier (2009), Azel calls his desire to leave Morocco his 'obsession' and 'madness' (10). Both novels foreground harraga as resulting from a collective sense of suffocation, from the experience of 'a life on hold' (Sansal 2005, 239). In this vein, Chérifa tells Lamia that she already left her hometown for Algiers because it was hell. My parents were getting on my nerves, they wanted me to stay home, wear the hidjab, hide myself. The emirs were prowling the area, they slit the girls' throats ... They want you to be a Muslim all the time, that's not a life!' (111). ${ }^{13}$

The stress on a desire to leave due to a sense of suffocation is important. As Lamia reflects, her brother Sofiane, who remains missing throughout the novel, had 'a house, my affection, friends, habits' (239). Yet, it is the feeling of blockage and the desire to live one's life with prospects - the pursuit of happiness, in other words - that both novels stress as the main incentive to leave, and both authors portray the desire to leave as so widespread that it has come to influence the entire social fabric. The image of Europe - and of Spain in particular in both of these novels - is held up against what is experienced as dogmatism and humiliation.

This sense of suffocation also exists in Ben Jelloun's novel, Leaving Tangier. Set in Tangier in the late 1990s, Leaving Tangier presents a network of characters who are all in one way or another affected by the 'project' of leaving Morocco. Each of the novel's forty chapters centres on one character, with some recurring more often than others. For example, Noureddine (a young man who drowned in an attempt to 'burn'), Soumaya (a woman from Oujda, who migrated to Spain with her husband, working in a Barcelona brothel after he left her) and Abdeslam (Noureddine's brother and 'an antideparture militant' [105] after seeing his brother's bloated corpse) each get a 
of her whereabouts after she has died in childbirth in a convent in Blida. Lamia adopts Chérifa's baby.
14 We have altered the translation here. For the French version, see Ben Jelloun (2006, 88). chapter. Others - like Azel (a young man, unemployed despite a law degree and many solicitations), Malika (Azel's teenage neighbour, who dies of pneumonia contracted while working in a shrimp-peeling factory) and Kenza (Azel's sister, who works as a nurse and leaves for Barcelona by contracting a fake marriage with Spanish gallery owner Miguel) - are focalizers in several chapters. The result is a narrative fabric that presents the frustrations, fears and hopes of a dense web of characters, who are all infected, to different degrees and in different ways, by the 'fever' of leaving.

Corresponding to this narrative structure, Leaving Tangier opens with a scene in a café overlooking the Strait of Gibraltar, where the different guests quietly 'stare at the horizon as if seeking to read their fate' (1). Among them is Azel, who shifts back and forth between trying to distinguish the first lights of the Spanish coast at nightfall, and illusions of his own inflated corpse floating in the sea, among other dead - 'naked bodies swollen by seawater, his face distorted by salt and longing, his skin burnt by the sun, split open across the chest as if there had been fighting before the boat went down' (2). And yet Azel - like the other characters - dreams of leaving Tangier for Spain. Europe beckons as a place of personal fulfilment and he describes 'his dream' (3) of Spain with words evoking liberation and rebirth: leaving promises 'being reborn elsewhere ... Spreading your wings. Running along the sand shouting out your freedom. Working, creating, producing, imagining, doing something with your life' (35). Azel notes that, like him, 'more and more young people today dream only of leaving, just leaving this country behind' (36), so that even teenaged Malika, Azel's neighbour, dreams of leaving (75). When Miguel, a rich gallery owner living in Barcelona and Tangier, offers to employ Azel in his Barcelona gallery, Azel takes the opportunity. On the day of his departure, he writes in an emphatic farewell letter to his country:

I finally have the opportunity and good fortune to go away, to leave you, to no longer breathe your air, no longer suffer the harassment and humiliations of your police. I set out, my heart light, eyes fixed on the horizon, gazing into the future. I don't know exactly what I will do - all I know is that I'm ready to change, ready to live freely, to be useful, to do things that will make me an upright man, no longer afraid. (Ben Jelloun 2009, 53-54) ${ }^{14}$

What he invokes here as motivation to leave are experiences of humiliation and impasse in his 'dear country' (53) and his hopes to gain more freedom, respect, and an open future on the other side of the sea. Both novels thus put in front of us, it seems, the urge to recall 'what has been promised under the name of Europe' (Derrida 1992, 76); that is, among other things and never perhaps sufficiently actualized, 'an idea of democracy' (78) and a continual critique of dogmatism and oppression. The novels 
invite us to examine what it would mean today to assume and to reactivate this dimension of a 'European' heritage, a dimension that the harragas forcefully reclaim and for which they are willing to migrate at great peril.

At the same time, it is very important to note that, even if both novels present the different characters' motives for leaving in these terms, neither of them idealizes harraga as an escape or offers it as a real solution. Instead, it is analysed as a collective response to sociopolitical circumstances that are experienced as stifling: its motives and hazards are examined; hopes of freedom and uprightness are shown to drive the harragas, but these hopes are also shown not to materialize. Already upon arrival, Azel notes that the small room in which he is staying feels walled off and stuffy (sent le renfermé) (Ben Jelloun 2006, 95). He received his visa and work permit under the tacit condition that he also becomes Miguel's lover, so that his situation is bound to sex- and work-services for Miguel. Increasingly reluctant to perform them, Azel eventually moves out, becoming a sans-papiers whose precarious status Ben Jelloun portrays in the last part of the novel. Ultimately, Azel's attempts to work himself out of his clandestine situation end with his murder by an Islamist brotherhood on whom he had consented to spy for the Spanish authorities. With this ending, and with neither Azel nor any other character achieving his or her dreams, Ben Jelloun clearly does not idealize harraga; yet, at the same time, the novel depicts with empathy the harragas' resilient dreams and their unyielding insistence that they might make a better life for themselves.

This same tension can also be found in Sansal's Harraga. For example, Chérifa - the young woman who moved in with Lamia - dies giving birth on the road, while the fate of Lamia's brother Sofiane remains uncertain until the end of the novel. And when the route of those who burn is directly depicted - Sansal has Lamia watch a TV documentary about a group of people migrating through the Sahara to the North, the camera accompanying them until their crossing of the Strait of Gibraltar - all but one lose their lives. Sansal presents harraga in its painful reality; yet in the documentary we hear the migrants en route dream of 'Europe, the pleasure of living, the joy of loving, and the rest...: the métro, social security, auto sport, snow, the cinema' (Sansal 2005, 229). Like Leaving Tangier, Harraga explores the brutalizing reality of clandestine migration and depicts the insistence of the migrants that harraga - despite its grave risks - might offer the 'pleasure of living'.

There is an important additional point that Sansal makes by including an account of a television documentary in his narrative; namely, that despite their eagerness to leave, the harragas are in no way ignorant of the dangers or naïve as to their prospects in Europe. Its dangers are televised not only in Europe (it is the French-German channel Arte that Lamia watches), but also in Algeria, Morocco and elsewhere. In Leaving Tangier, Abbas, one of 
Azel's clandestine friends in Barcelona, notes that even if people in Morocco might dream of Spain as 'an earthly paradise ... deep down they know the truth, they watch TV, they can see how we're being treated here, they know it's not heaven' (126). Malika, already hospitalized with pneumonia, stops dreaming of leaving the country after she 'had seen the pictures of floating bodies on television' (94). And yet, when her condition worsens, she is gripped by the fear of 'dying - leaving without realizing her dream, leaving without ever having left the country' (146). Despite awareness of the dangers, the fortified borders, the disregard of Europe for those on the other side, despite all of this, in Harraga Lamia thinks to herself after watching the documentary:

Dying is a risk to take

If living is possible

An elsewhere is worth a thousand heres.

Let's burn up the road

The promised Land is somewhere in the world. (Sansal 2005, 240)

Having considered the novels' complex accounts of harraga, we can now return to the question of how exactly we are to read these headings, undertaken at the risk of death. What can we discern from the novels' presentations in view of a critique of Europe? And what would it mean to respond to - or, as Derrida adds, 'to be responsible for? To respond for? To respond, be responsible, before?' (1992, 53) - such a critique? A response to these questions would require much more than interlacing these three texts. But perhaps, for now, we can consider the critique of Europe that these literary examinations of harraga offer and how such a critique can be folded back upon the question of the headings of Europe with which we started.

\section{A Renewed Critique of Europe; or, The Other of the Heading?}

Sansal and Ben Jelloun's novels offer complex accounts of the phenomenon of harraga, starting with a critique of the current heading of Europe - of which harraga, as we have suggested above, is part and parcel. Both novels vividly show the effects of fortified European borders, present in one way or another in each of the characters' stories. They specifically address the racialized violence that complements closed borders - in particular, Leaving Tangier thematizes the disregard of Europe for 'the other side, for the "Moroccans", los moros, as they call them' (167). On the day of his arrival in Barcelona, Azel notes that 'from Morocco you can see Spain, but it doesn't work like that in the opposite 
direction. The Spanish don't see us, they don't give a damn' (58). One effect of such indifference is that the consequences of neoliberal outsourcing of labour can also remain concealed from Europe. The harshest example Leaving Tangier gives in this regard is Malika's story, who, 'like her girlfriend Achoucha, the neighbour lady Hafsa, her cousin Fatima, and hundreds of girls in her neighbourhood' (77), worked in a shrimp factory in Tangier, where she contracted pneumonia while peeling shrimps for the EU market.

In addition to a critique of this direction Europe takes today, the novels also critically examine the present route taken by North African nations - most of all Algeria and Morocco, but both novels also exemplarily include other African nations (Chad and Niger via the documentary in Harraga; Cameroun via Flaubert, a character in Leaving Tangier). They expose the sociopolitical conditions that drive people to leave. As Lamia in Harraga reflects, it is a complex mix of factors that prompted her brother Sofiane and all the others to 'burn' - 'the green plague' (138), referring to Islamism, along with the 'the culture of crime, of the coup, of the clan, the apologetics of death, the glorification of the tyrant, the love of gewgaw, the passion for demagoguery' (239). At the end of the novel, praying at Chérifa's grave, Lamia is again explicit about this destructive heading of Algeria:

This country is governed by people without a soul, they have made of us beings in their liking, small, malicious and greedy or insurgents who shrivel in shame and insignificance. Our children suffer, they dream of fortune, love and games, they train them in evil, hatred and idleness. They have only this means to live, to become harraga, burn up the road. (Sansal, 2005, 314)

And yet, while the novels uncover the reasons that push people to leave, on a third level they also critically examine the headings of the harragas themselves: these are portrayed as a collective obsession, a communal fever despite an awareness of the slim chances of success or even survival. Lamia keeps calling Sofiane her 'idiot of a brother' (314) and, not without sarcasm and irritation, she also calls the phenomenon harraga itself 'collective suicide' (132). The harragas have invented nothing but a new way of dying for us, Lamia thinks, and those who make it across the sea lose 'their soul in the worse realm there is: clandestine life' (54). In Leaving Tangier, Moha - a character central to Ben Jelloun's earlier novel Moha le Fou, Moha le Sage (1978), and there a figure part-madman part-sage - similarly deplores 'heading off' as currently the only response to the stifling conditions that people have come up with: 'Leaving! Leaving! Leaving any way at all, at any cost, drowning, floating on the water, belly bloated ... Leaving! That's all you've come up with for a solution' (118). In his earlier novel, Ben Jelloun used Moha to voice a critique of the system of repression, torture and injustice in Morocco in the mid-1970s. In Leaving Tangier he has him 
reappear as a voice that criticizes harraga as (literally) misguided. One should, rather, Moha suggests, change direction. Knowing that the Europeans are 'not expecting you, or rather, they are: with dogs ..., handcuffs, a kick in the butt' (116), his proposition is to turn south instead - 'burn up the desert' (116). And yet, even as Moha briefly raises the possibility of heading in another direction - 'I'm heading for Africa, land of our ancestors, vast Africa' (117) - he himself, after his criticism of heading north, decides to change heading altogether and stays to care for Malika on her deathbed. After his speech against leaving - a monologue addressed to the reader more than to any character - he concludes:

I'll shut up ... give me a glass of water, little Malika needs me, she's coughing, she's sick, she caught pneumonia from shelling shrimp in the cold, we have to get her some medicines, her parents can't afford them, I'm going to take up a collection, we have to save her, she's a lovely girl who deserves to live, laugh, dance ... Leaving! That's all you've come up with for a solution. (Ben Jelloun 2009, 118)

Ben Jelloun and Sansal expose these multiple layers of harraga-implicated in and with Europe. Without condemning or idealizing, they present the dense web of circumstances and misguided directions, and their novels gesture at the necessity of changing the heading in all three dimensions: the heading of Europe, the headings of the North African nations, and the heading of the harragas. This might mean - to speak with Derrida - 'to change goals, to decide on another heading, or else to change captains, or even - why not? - the age or sex of the captain' $(1992,14-15)$, and it seems to be more than merely incidental that Moha decides to stay for young Malika, and that Lamia stays for Chérifa's baby girl: staying (or re-turning) to alter the circumstances at hand, to board a (ghostly) ship as the characters at the end of Leaving Tangier do, 'without knowing its destination' (211) ... seems to be the noteworthy 'other of the heading' that suggests itself here.

Before closing, we would like to stay with the last point of the heading of the harragas for just a moment. While the novels question the obsession with leaving as a dead-end, it is crucial to note that although the direction is presented as problematic, the motives for leaving and the critique the harragas thereby utter is not. Frustrated by the lack of respect and prospects the characters experience on both sides of the sea, by the religious or political dogmatism that prevents them from breathing freely in both geopolitical hemispheres, they collectively insist on their right to live their lives, even if it means pursuing this at great peril. Both novels quite overtly affirm these motives of harraga - and it is in view of these that all changes of headings have to be demanded, if we hear Sansal and Ben Jelloun correctly. The characters' frustrations and desires are presented as justified without idealizing the decision to leave, and we have tried to unfold them here. Even if by leaving the 
characters actualize their desires in ways that the novels portray as ultimately failing or leading nowhere, what the harragas nevertheless very forcefully do is insist - on and for all sides - on more open futures, a space to breathe and the continual work on freedom from oppression and exploitation. We might say - to speak with Derrida again, and once more return to the point of Europe - they 'assume the ... heritage of an idea of democracy' $(1992,78)$, a heritage that implies, among other things, 'criticizing ... totalitarian dogmatism' (77). They recall to 'us' - to quote this passage again - 'what has been promised under the name Europe' and challenge 'us' 'to re-identify Europe' (76) in view of this. If 'we' ventured in that direction, such an 'us' could then no longer mean Europeans de souche, but anyone touched by and involved in a Europe that would be reidentified thus; and this 'we' would have to redefine itself over the course of such other (of) headings. If 'we' took the harragas' call and recall to heart, 'we' might see that what has been promised under the name 'Europe' also 'dictates opening Europe ...; welcoming foreigners in order to ... recognize and accept their alterity' (77) - welcoming all foreigners, willing to 'discern the unprecedented forms that [this duty] is taking today in Europe' (80). It would be a game-changer, in all directions (due to the nature of entanglement, as we have employed the term here). Again, this is not a new point, but still the point of Europe today.

\section{References}

Abderrezak, Hakim. 2009. "Burning the Sea: Clandestine Migration Across the Strait of Gibraltar in Francophone Moroccan 'Illiterature'." Contemporary French and Francophone Studies 13 (4): 461-469.

Abderrezak, Hakim. 2010. "Entretien avec Boualem Sansal." Contemporary French and Francophone Studies 14 (4): 339-347.

Ahluwalia, Pal. 2010. Out of Africa: Post-structuralism's Colonial Roots. New York: Routledge.

Barad, Karen. 2007. Meeting the Universe Halfway: Quantum Physics and the Entanglement of Matter and Meaning. Durham, NC: Duke University Press.

Barad, Karen. 2014. "Diffracting Diffraction: Cutting Together-Apart.” Parallax 20 (3): 168-187.

Ben Jelloun, Tahar. 2006. Partir. Paris: Éditions Gallimard.

Ben Jelloun, Tahar. 2009. Leaving Tangier. London: Arcadia Books.

Carr, Matthew. 2012. Fortress Europe: Dispatches from a Gated Continent. London: C. Hurst.

Chakrabarty, Dipesh. 2000. Provincializing Europe: Postcolonial Thought and Historical Difference. Princeton: Princeton University Press.
Chérif, Mustapha, ed. 2008a. Derrida à Alger. Un regard sur le monde. Arles: Actes Sud.

Chérif, Mustapha. 2008b. Islam and the West. A Conversation with Jacques Derrida. Translated by Teresa Lavender Fagan. Chicago: University of Chicago Press.

Derrida, Jacques. 1991. “Circonfession.” In Jacques Derrida, edited by Jacques Derrida and Geoffrey Bennington, 7-291. Paris: Éditions du Seuil.

Derrida, Jacques. 1992. The Other Heading. Bloomington: Indiana University Press.

Derrida, Jacques. 1996. Le Monolinguisme de l'autre: $\mathrm{Ou}$ le prothèse d'origine. Paris: Éditions Galilée.

Derrida, Jacques. 2002. H. C. pour la vie, c'est à dire ... Paris: Éditions Galilée.

El-Tayeb, Fatima. 2011. European Others: Queering Ethnicity in Postnational Europe. Minneapolis: University of Minnesota Press.

Frontex. 2013. "FRAN Quarterly - Quarter 3, JulySeptember 2013.” Accessed 10 September 2014. http://frontex.europa.eu/assets/Publications/Risk_ Analysis/FRAN_Q3_2013.pdf. 
Gilroy, Paul. 2005. Postcolonial Melancholia. New York: Columbia University Press.

Haraway, Donna. 1997. Modest_Witness@Second_Millennium: FemaleMan@_Meets_OncoMouse ${ }^{\mathrm{TM}}$. New York: Routledge.

Hiddleston, Jane. 2010. Poststructuralism and Postcoloniality: The Anxiety of Theory. Liverpool: Liverpool University Press.

Kaiser, Birgit M., and Kathrin Thiele. 2014. Diffracted Worlds - Diffractive Readings: Onto-Epistemologies and the Critical Humanities. Special Issue Parallax 20 (3): 165-289.

Kirby, Vicki. 2011. Quantum Anthropologies: Life at Large. Durham, NC: Duke University Press.

Latour, Bruno. 2004. "Why Has Critique Run Out of Steam? From Matters of Facts to Matters of Concern." Critical Inquiry 30 (2): 225-248.

Poel, Ieme van der. 2011. "Le drame des "harragas" vu de près et de loin: Youssef Amine Elalamy rencontre Hafid Bouazza." In Littératures africaines et comparatisme, edited by Florence Paravy, 155-170. Metz: Université Lorraine Ecritures.
Puar, Jasbir K. 2007. Terrorist Assemblages: Homonationalism in Queer Times. Durham, NC: Duke University Press.

Puig de la Bellacasa, Maria. 2011. "Matters of Care in Technoscience: Assembling Neglected Things." Social Studies of Science 41 (1): 85-106.

Redouane, Najib. 2008. Clandestins dans le texte maghrébin de langue française. Paris: L'Harmattan.

Sansal, Boualem. 2005. Harraga. Paris: Éditions Gallimard

Sassen, Saskia. 2014. Expulsions: Brutality and Complexity in the Global Economy. Cambridge, MA: Harvard University Press.

UNHCR. 2013. "Mediterranean Crossings to Italy and Malta Exceed 8000 in First Six Months of 2013." UNHCR, 5 July. Accessed 10 September 2014. http://www.unhcr.org/51d6a0859.html.

Yildiz, Yasemin. 2012. Beyond the Mother Tongue: The Postmonolingual Condition. New York: Fordham University Press.

Young, Robert J. C. 1990. White Mythologies: Writing History and the West. London: Routledge. 